\title{
An unusually extensive internal jugular vein thrombosis
}

\author{
Savvas Hadjiphilippou, ${ }^{1}$ Dean Y Huang ${ }^{2}$
}

${ }^{1}$ Department of Nephrology, King's College Hospital, London, UK

2Department of Radiology, King's College Hospital, London, UK

\section{Correspondence to} Dr Savvas Hadjiphilippou, s.hadjiphilippou@nhs.net
CrossMark

To cite: Hadjiphilippou S, Huang DY. BMJ Case Rep Published online: [please include Day Month Year] doi:10.1136/bcr-2013202034

\section{DESCRIPTION}

A 45-year-old female haemodialysis patient was admitted with a 10-day history of left-sided throbbing submandibular pain and swelling. She had presented with fever and left-sided neck pain to accident and emergency 3 days ago and was discharged home with antibiotics for presumed cellulitis. A left internal jugular tunnelled line for haemodialysis was inserted 6 weeks ago but she did not spike fevers or develop pain on dialysis and there was no line tenderness.

On examination, diffuse left-sided neck swelling and tenderness was noted over the submandibular region. She could not open her mouth fully and had odynophagia. She was afebrile but had a C reactive protein of $189 \mathrm{mg} / \mathrm{L}$. An ultrasound examination of the neck (figure 1) demonstrated a left internal jugular vein (IJV) thrombosis. A subsequent contrast-enhanced CT examination of her neck (figure 2) revealed the extensiveness of the thrombus, extending from the skull base to the left brachiocephalic vein. She was started on intravenous heparin prior to warfarin loading and was treated with 7 days of intravenous vancomycin and gentamicin. Following treatment, her symptoms resolved.

IJV thrombosis is a rare condition. This is commonly caused by central vein catheterisation, malignancy or injection by intravenous drug users. ${ }^{1}$ Patients with IJV thrombosis typically present with neck pain and swelling. ${ }^{2}$ The most severe consequence of extensive IJV thrombosis is clinically significant pulmonary embolism. ${ }^{2}$ Despite limited consensus on treatments, this is generally managed

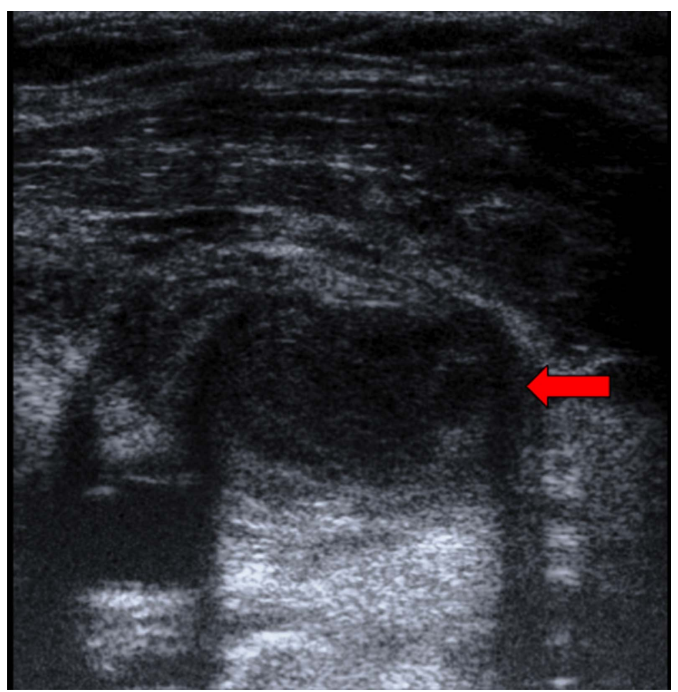

Figure 1 An axial image of ultrasound examination of the left internal jugular vein, which demonstrates an enlarged, incompressible thrombosed left internal jugular vein (red arrow) with loss of normal echopoor intraluminal appearances.

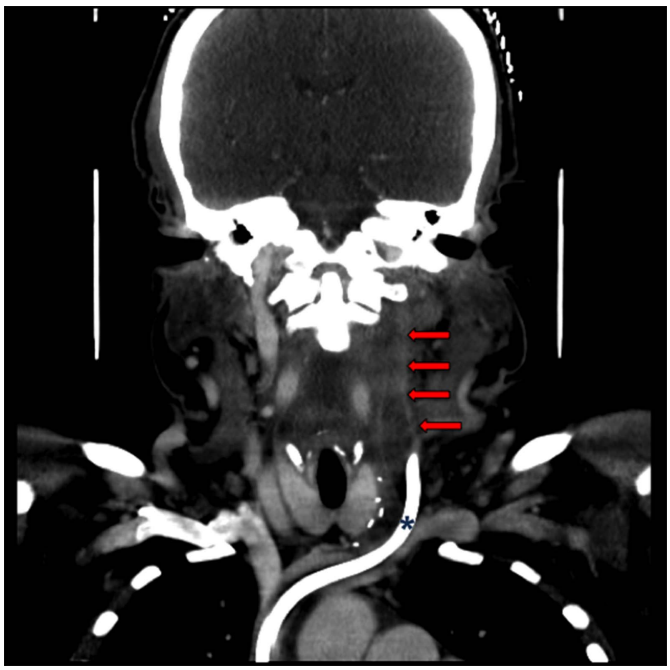

Figure 2 A coronal image of the contrast-enhanced CT of the neck reveals the left internal jugular vein thrombosis extending from the skull base to the left brachiocephalic vein (red arrows). Associated inflammatory changes with increased CT density are noted surrounding the thrombosed left internal jugular vein. A note is made of the presence of a tunnelled dialysis line inserted at the proximal left internal jugular vein (blue asterisk).

with anticoagulation aimed at preventing thrombus propagation together with antibiotics if there is evidence of infection.

\section{Learning points}

- In patients with lines in situ who present with atypical clinical features, extensive thrombus and associated thrombophlebitis should always be considered.

- Imaging should include central and distal to the site of maximal tenderness, as thrombi can be unusually extensive in nature.

- A contrast-enhanced cross-sectional imaging examination (CT or MRI) may be required to fully evaluate the extensiveness of venous thrombosis.

Contributors SH and DYH contributed to the design and drafting of the article and have approved the submitted final version of the manuscript.

Competing interests None.

Patient consent Obtained.

Provenance and peer review Not commissioned; externally peer reviewed. 


\section{REFERENCES}

1 Ball $E$, Morris-Stiff G, Coxon M, et al. Internal jugular vein thrombosis in a warfarinised patient: a case report. J Med Case Rep 2007;20:184.
2 Gbaguidi X, Janvresse A, Benichou J, et al. Internal jugular vein thrombosis: outcome and risk factors. QJM 2011;104:209-19.

Copyright 2013 BMJ Publishing Group. All rights reserved. For permission to reuse any of this content visit http://group.bmj.com/group/rights-licensing/permissions.

BMJ Case Report Fellows may re-use this article for personal use and teaching without any further permission.

Become a Fellow of BMJ Case Reports today and you can:

- Submit as many cases as you like

- Enjoy fast sympathetic peer review and rapid publication of accepted articles

- Access all the published articles

- Re-use any of the published material for personal use and teaching without further permission

For information on Institutional Fellowships contact consortiasales@bmjgroup.com

Visit casereports.bmj.com for more articles like this and to become a Fellow 